\title{
8 Data governance in the Basque Country
}

\section{Victims and memories of violent conflicts ${ }^{1}$}

\author{
Joxerramon Bengoetxea
}

\section{Introduction}

When there have been episodes of conflict and violence affecting the living together of peoples that identify themselves as distinct in a common territory, a key issue is how such conflict will be told and explained. Ownership over the conflict, and all the relevant data related to it, becomes crucial, and contentious. In the Spanish context, we can consider the ongoing political conflict in Catalonia and, to a lesser degree, in the Basque Country, as competing sovereignty claims. Whereas the Basque conflict (1968-2011) has been "infected" by terrorism and counterterrorism, the recent Catalan process (2014) has been peaceful, and generally perceived as such.

This contribution is about sovereignty and empowerment, not in the sense of secession, self-determination or autonomy, but over data. Data sovereignty or data governance is a broad theme concerning all "registered" and quantifiable knowledge regarding a people and the possibilities for such people to shape and own the data and the knowledge they originate or reflect. The data reflect a preconfigured type of knowledge that they represent; but data, once organized and "institutionalized" also generate knowledge, creating narratives about peoples, or their culture. This contribution tests and questions the very idea of autochthonous data sovereignty as regards data and narratives - constructed from such data - in the context of political violence in the Basque Country, more particularly victims and memory. Different actors with different agendas in the Basque political "conflict" relate to different data in order to construct or reflect competing narratives over collective memory and collective identity.

Two major differences of outlook can be identified: periodization of the "conflicto" (historical memory) and categorization of the victim/victimizer dynamics. Different moral conclusions are drawn from data-based narratives. They look into different historical moments of victimization or, when looking at the same period of violence and conflict, their categories of victims and victimizers are used in different ways, leading to different politics of memory. Periodization turns around the question how far back to go in the history of conflict: the Civil War, the dictatorship, the rise of ETA until the death of Franco, the transition and the Amnesty Act, the devolution of powers to the Basque Country and finally, the rise of Islamist Salafi terrorism. 
The largest number of victims and human rights breaches took place in the years 1936-1945. Yet, this violent period of Spanish history is not present in the agenda on victims of terrorism. It is history: the agenda of the past. The "memory of the victims" in Spain normally refers, almost exclusively, to the victims of ETA violence. This is the present, recent or current agenda. Paradoxically, ETA's final ceasefire in 2011 seems to have had little impact on this agenda. The other conflicts, even the other victims in the ETA conflict are second-class victims, because they do not fit into the normative allocation of moral virtues and blame prevailing in the Spanish criminal justice system and political culture.

This is a classic use of data: to build a narrative that captures the supposed essence and experience of a group of people - victims - and defends their collective interests. In highlighting the contrast between the different political uses of "data" this chapter speaks to a key issue for data sovereignty, which suggests, among other things, the power to shape prevailing ideas of peoplehood, or victimhood, through data and narratives built around them.

\section{Background to the Basque conflict}

In the Basque Country, the "conflict" can be described politically as turning around the question of sovereignty, the struggle for self-government and recognition as a "people". The claims range from self-government to self-determination-a right to decide on political status - or to independence or secession. There are two major moments in the last hundred years of Spanish Basque conflict: one "historical", the other, "recent". The historical conflict was the result of the Franco dictatorship. The Basque Country (and Catalonia) achieved an autonomous status in Spain toward the end of the Second Spanish Republic (1936) but a coup d'Etat followed by Civil War and the Franco dictatorship brought an end to this freedom and left a record of thousands killed, summarily executed, disappeared or exiled. A recent report on mortal victims during the Civil War and the first years of the dictatorship (1936-1945) elaborated by the Basque Government, with the Chair of Human Rights of the University of the Basque Country and the Natural Sciences Institute, Aranzadi, has established that approximately 20,000 Basques were killed in that period, and 5887 of those deaths can be considered crimes against humanity. Most victims were in the Republican camp (but 955 were victims of Republican fire outside combat): 2252 died in prison, 1363 in bombings like the Gernika bombings that killed civilians, 895 were summarily executed and 1130 were extra-judicially executed. Repression in Franco's Spain was brutal and yet there was no experience of transitional justice of any sort in constitutional Spain until the Act of Historical Memory (2007). Some autonomous communities in Spain-Andalusia, Extremadura, Navarre-have adopted their own historical memory Acts and the Basque Country institutions are drafting a Bill on this issue (2019) following a popular legislative initiative.

The recent Basque conflict has been violent and created suffering and pain. When ETA was set up during the dictatorship (1958), memory of the Civil War and of the most violent repression of the Franco regime on political opponents 
(1936-1945) was fresh. Ten years after its creation, ETA murdered its first intended victim, Melitón Manzanas, ${ }^{2}$ head of the "social-political brigades" of the Spanish police in San Sebastian and former collaborator of the Gestapo. Because of his direct involvement in Human Rights violations and tortures he would count as victim and victimizer. This paradoxic twist raises the issue of moral and political ambiguity, which is difficult to reflect in the collection of data on victims.

The Basque Country, and Spain as a whole, have gone through a violent history over half a century. ETA murdered 837 persons. Thousands of persons were injured (3000), others were kidnapped, threatened, driven to pay ransom, so-called "revolutionary tax". Many of the victims were police or military but large numbers were civilians, Basque and Spanish. The fight against ETA by the Spanish State and Security Forces also produced victims of violence and human rights breaches (torture, paramilitary groups with ministerial involvement, shooting at demonstrators) and the criminal justice system has also produced much pain through official or lawful but over-punitive measures like large prison sentences, serving sentence in far-away prisons, abuse of preventive prison, confinement, not releasing seriously ill prisoners, amongst other measures. Dating that conflict is a contentious issue on its own: how far back do you go? Identifying the nature and ideology of the actors involved in the conflict is also a delicate task. As regards ETA, the best analysis to date is still Bullain's (2011). Transnational discourse and categories of "the fight against terrorism" have permeated the perception. The definition of the different elements or features of the conflict become very problematic: are there good and evil actors? Who defines the conflict? Who is a victim? How should prisoners be treated, and in what territory?

This contribution therefore intends to place these contentious issues in the broader discourse of Indigenousness (indigeneité) and data governance. Not all facets of the conflict can be analyzed here. We have selected the question of memory and data on victims to test the relevance and adequacy of the Indigenous Data Sovereignty discourse. Indigenous Peoples around the world have experienced violence and have a memory of violence and pain. Conflicts and struggles are an important part of their collective memory. Be it in the form of colonization, forced assimilation, deprivation of land and resources, neglect of cultural sites and traditions, and in more extreme forms of racial hatred, genocide, ethnocide. But are Basques a possible Indigenous case?

\section{The Basques as an Indigenous People or as a minority}

In order to know how to qualify the Basque People we would need to analyze the European system of governance, which shies away from the collective rights of Peoples, and rather focuses on the individual rights of the members of a national minority. The United Nations Declaration on the Rights of Indigenous Peoples (UNDRIP) does not define Indigenous People (IP); it gives a series of criteria of recognition, amongst which the subjective element is prominent. Indeed, selfidentification of a people as an Indigenous People impregnates the UNDRIP. 
The Basque People are established in several territories, the historical territories: three in the French Pays Basque, three in the Spanish Autonomous Community of the Basque Country, and the Spanish Foral Community of Navarre. There is also an important Basque diaspora, dispersed around the whole world, with some significant communities. The key subjective criterion of self-identification would need to enquire how the Basques in these territories see themselves: as an ethnic group, as a distinct original people, as a pristine people, as a demos, as a Nation, as a minority, as an Indigenous People, as Aboriginal, as First Peoples, First Nation or First Settlers, as part of the Spanish or French people, and so on. There are almost as many self-identifications as there are Basques.

The modern objective or substantive concept of Indigenous People points to the existence of an ethnic group, with a distinctive culture, that enjoys quasisovereign status and related rights like the right to self-determination, the right to land traditionally owned or occupied, the right to language. These rights are recognized in the UNDRIP. The IP would organize around autonomous and representative organizations that would account for a special "system" of governance. According to this substantive approach, there are no compelling reasons to rule out the Basques as an Indigenous People.

There is also a procedural approach to the concept of IP and it has much to do with the issue of prevalence: a minority people who were the first to settle in a certain territory but subsequently became a minority in the territory because of the prevalence of a different dominant people. This discourse can be found in many cases of IP, but not so clearly in the Basque Country, which is why "minority" is only a meaningful term if one considers Spain as a whole. If we follow this procedural approach, we relate back to the conflict on sovereignty. In spite of serious difficulties of definition and classification, we can provisionally hold that there are no sufficient grounds for considering Basques as Indigenous Peoples, mostly because they do not identify themselves as such. Similarly, Basques are not a minority within the Basque Country. Basques favor other collective identifications like ethnic group and nation. But there are equally no solid objections to deny that some Basques, individually, may consider themselves, or identify as Indigenous, and collectively, Basques make some cultural, political and legal claims they share with typical claims of IP, claims based on international law instruments.

Some typical issues of concern regarding the rights and claims of Indigenous Peoples following from UNDRIP are shared with national minorities as they follow from the European Framework Convention and from the Charter, but the UNDRIP goes considerably further in recognizing a rich panoply of rights. The typical claims made by IP and recognized in the Declaration are familiar for Basque ethnicity and politics. The rights and claims following from the UNDRIP have a collective dimension, that may occasionally need to be weighed and balanced with individual rights. Potential clashes can sometimes be the result of inter-sectorialities following from multiple identities that have traditionally suffered discrimination like being an Indigenous citizen speaking an Indigenous language, being a woman, and being homosexual. Rights recognized internationally 
need balancing in concrete situations and identities are often layered or patched together. Indigenous women can suffer additional violence and discrimination within their group, and homosexuality may not always be accepted, and overcoming the categories and exclusions is not easy for any of the actors concerned. This potential conflict raises the issue of intersectional or inter-sector identities but also that of individual rights of a collective nature, so typical of the European approach.

The Council of Europe has adopted important instruments using a different vocabulary. The most important ones are the Language Charter for Regional or Minority Languages and the Framework Convention for the Protection of National Minorities. The UNDRIP excludes Western Europe from the panoply of world regions where IP are present and this exclusion could mislead observers to conclude that Western Europe is free from the type of situations and normative claims made by IP as regards the procedural approach mentioned above. However, the Council of Europe has been dealing with similar concerns for decades. Issues like the protection and promotion of languages used by traditional minorities or the broader commitment to the protection of national minorities are the subject of two major instruments, i.e., the European Charter for Regional or Minority Languages (the Charter) and the Framework Convention for the Protection of National Minorities (the Framework Convention). Their relevance to the Basque Country is still under-explored and Basque politics have not really looked at the notion of national minorities, albeit the widespread identification of the Basque Country as a (minority) nation. The application of the national minority category to Spain by the Council of Europe monitoring mechanism has so far only looked at the Roma people. The category "minority" can be misleading and the existence of specific instruments - the European Charter of Local Self-Government and the Congress of Local and Regional Authorities-for the recognition of local and regional autonomy in Europe raises specific questions about labeling and identity. The political agenda in Spain has not really paid much attention to the rights of members of national minorities recognized by the State, probably because signatory states can adapt the framework convention's rights to their specific internal situations and therefore, non-observance has practically no legal or political consequence, unlike the human rights recognized in the European Convention.

Like the UNDRIP as regards IP, the Framework Convention does not contain a definition of "national minority" as there is no general definition agreed upon by all Council of Europe member states. Each party of the Framework Convention is therefore left with a margin of appreciation to assess which groups are to be covered by the Convention within their territory. A pragmatic approach was adopted, based on the recognition that at this stage, it is impossible to arrive at a definition capable of mustering general support of all Council of Europe member States. This decision must be made in good faith and in accordance with general principles of international law, including the principle of free self-identification, set out in Article 3 of the Framework Convention. But unlike the UNDRIP, this is an individual right: individuals may decide themselves whether they wish to be treated as belonging to a national minority or not. However, their decision must 
be based on objective criteria connected with their identity, such as their religion, language, traditions and cultural heritage.

Obtaining accurate statistics on the size of minority populations in European states is very difficult. Ethnic profiling in statistics is often prohibited. Many states do not disaggregate data on ethnic grounds for a variety of historical and political reasons and partly because states do not have reliable or up-to-date census figures. Religion can also be a taboo. Virtually all states in Europe have some population belonging to national minorities, but not all states recognize them. Sometimes this clashes with ideas of Republican equality (meaning citizen uniformity, as in France). Migrant communities, however, are not considered national minorities, within the scope of the European instruments.

Some of the key rights and obligations of the European instruments relate to the European Convention of Human Rights - freedom of expression and thought, of assembly-association, of information and others remind us of the UNDRIPfreedom to use the language in private and public, also in relation to administrative authorities where the request coming from areas inhabited by national minorities or in substantial numbers, "corresponds to a real need" (Art 10, 2nd paragraph), freedom to use their personal and place names and have them officially recognized (Article 11), education, including setting up their own schools in their language and of their language (Articles 12, 13 and 14 ). But the difficulty still lies in the identification of the subjects and right-holders. Identifying the subjects of the obligations is not problematic: States are the parties to the treaties. This sometimes leads to a difficult balance: national minorities exist, objectively, but they do not hold collective rights. Individuals can hold rights as members of national minorities. A tertium datur seems to emerge between the States and the individuals: national minorities. They have no rights and no obligations, but they are the source of individual rights and state obligations, as long as the state recognizes them.

Whatever the approach to the qualification of a people as Indigenous or minority - subjective, objective or procedural — data on the people concerned becomes a necessary tool. This requires examining the issue of data and sovereignty over data, even of data about sovereignty. Instead of data sovereignty we prefer to analyze it in terms of data governance.

\section{Data governance of Indigenous and minority nations. The Basque data ecosystem}

Can data be Indigenous, universal or local? There often is a perception of data as being neutral, just numbers, but this is misleading. Indigenous data refers to data information or knowledge, in whatever format or medium, about IP, or from IP, or that affects IP either collectively or individually, and ranges from language, to genetic data, environment or resources. These data can be on/about IP, data for IP (for them to access and make use of) and data of/by IP: knowing the data, owning the data, need to collect directly (Rainie et al. 2019). The scope of the Indigenous data ecosystem is vast and includes data generated or held by 
Indigenous communities and organizations, governments, the public sector, international governmental organizations (IGOs), NGOs, research institutions and commercial entities. (Kukutai and Taylor 2016: 2).

The idea of "data sovereignty" can be seen as a derivative of the complex equation combining official and private mechanisms for "datafying" reality. The official records include statistics and the registry of personal data—such as identity, education degrees, health records and property - such as land and buildings, movables, shares, inheritance, trusts, intellectual property - and the private collection of information - such as consumer data, market data, products and goods data, banking and insurance data, commercial data - and all this information has increased exponentially in the digital age. Awareness of the existence of this immense but hardly visible digital dimension becomes crucial (Lovett et al. 2019).

Datafication is a descriptive concept, signaling some significant social and economic dynamics currently taking place. Everything about life, and death, that can be datafied will eventually be. But who, and for what purpose, is collecting and processing the data? Consequences depend on the type of data stored, the techniques used and on who decides about the knowledge and authority issues. Information on the many instances of collecting data is not always easy to obtain. Big data in the digital age and nation-state jurisdiction - data superhighways over such data are going in different, sometimes opposite, directions (Cossins 2018). Transfer of data from one state to another often take place without the persons concerned knowing their data will be accessed by external governments. Indeed, statistics are linked to the science of state governance and administration. Indigenous Nations, and also minority Nations or national minorities are now asserting their own claims to data, registries and statistics, to all information concerning them, often disguised as "neutral" data. Knowledge infrastructures become necessary. These counter-hegemonic claims are rooted in their inherent rights to self-identification and self-determination as Peoples. Indigenous Data Sovereignty thus refers to the proper locus of authority over the governance of data about such Peoples, their territories and ways of life (Walter 2018).

But the claim to control data concerning people is also of direct concern to individuals, whatever their civil and citizen status, cultural and ethnic identity. The EU General Regulation on Data Protection that entered into force in 2018 is one of the most sophisticated normative developments over personal data collection, data use and the rights of individuals concerning their personal data. Empowering the individuals to understand the impact of data collection on their lives and welfare, to adopt the decisions concerning such data and regain control as citizens becomes of the essence. For IP there are additional and special concerns, as addressed in this book. In essence they involve a transition and awareness that moves from "my data" to "our data", creating citizen and people mindscapes, where relevant data are sorted out from data spam, secondary data are organized after all the necessary "cleaning" and relevant missing data are also identified. Repair and maintenance are important because they allow us to challenge linear thinking about big data. And the question of algorithms applied to the data follows next. 
In the Kukutai and Taylor (2016) preface, Victoria Tauli-Corpuz UN Special Rapporteur on the Rights of Indigenous Peoples writes:

The United Nations Permanent Forum on Indigenous Issues in its first and second sessions $(2002,2003)$ already recognised that a key challenge faced by national and international bodies is the lack of disaggregated data on Indigenous Peoples. The absence or lack of data that reflect where and how many Indigenous Peoples there are, and how they are faring in relation to the realization of their individual and collective rights is directly related to the weakness of governments and intergovernmental bodies in formulating and implementing Indigenous-sensitive decisions and programs.

Indigenous Data Sovereignty thus refers to the inherent rights and interests IP have in relation to the creation, collection, access, analysis, interpretation, management, dissemination, re-use and control of data relating to IP, and to decide what, how and why such data are collected, accessed and used.

(Kukutai and Taylor 2016: xi)

In a sense, it implies moving from data about to data for or by IP, but it is also, more ambitiously, a decolonizing methodology, a new epistemology capturing different world-views. ${ }^{3}$

Kukutai and Taylor frame their argument in terms of IPs' rights to self-determination (Article 3, UNDRIP), in relation to their political status and their economic, social and cultural development. But Indigenous Data Sovereignty is also about the resources and capabilities to collect and process data on your own people. This is the approach adopted by Snipp (2016: 40)

That Indigenous people are typically poorer than the surrounding settler state has important implications for data sovereignty. This is because collecting data that can be turned into information and later organized into meaningful knowledge is a costly process. Censuses and surveys are very costly to conduct and even unobtrusive video surveillance must be processed to condense it and make it intelligible. This, too, often means that Indigenous communities must forgo having access to certain types of information about themselves or must rely on outsiders with the requisite resources to obtain this information. Of course, relying on outsiders typically involves significant compromises over the control of data and therefore data sovereignty."

Would it be conceivable, for instance, for an Indigenous People to have their own Internet domain dot $x$ as in .nz or .uk or .eus for the Basque Country? Digital spaces are crucial new data ecosystems.

While the Western idea of 'data sovereignty' can be seen as a product of the digital age and nation-state jurisdiction over such data, Indigenous nations are asserting their own claims to data sovereignty, which are rooted in their 
inherent rights to self-determination as sovereign entities predating European settlers. Indigenous Data Sovereignty thus refers to the proper locus of authority over the management of data about Indigenous peoples, their territories and ways of life.

(Kukutai and Taylor 2016: 14)

Indigenous engagement in the setting of relevant indicators will be a key issue in the post-2015 UN development agenda built around the new Sustainable Development Goals (SDGs) (Kukutai and Taylor 2016: 5). Looking to the past but also to the future to consider how much of the past it is essential to preserve and project into the future, is essential in order to make sure that important values and legitimate interests are considered and reflected in the data governance.

\section{Autonomous data governance in the Basque Country}

Indigenous Data Sovereignty, as a field of study, could also be useful to describe and explain some interesting initiatives that are taking place in the Basque Country with a view to generating and preserving data and statistics for a territory that is not in line with the official demarcation. As explained in the introduction, the Basque Country is perceived as a cultural and "ethnic" community by many Basques, but there is no "official" administration, or common entity bringing together all seven Basque territories. It is therefore important to visualize the Basque People in their territorial complexity, and thus go beyond the official states - Spain and France - and European administrative regions - in order to take account of the complex territorial and identity dimensions of the Basque territories. Eustat is the statistical office of the Basque Autonomous Community and is restricted to data collection in the three territories of the Basque Autonomous Community. Its statistics are official. But there is an interesting, non-official and informal not-for-profit organization generating statistics and collecting data from different sources related to the economy, social relations and culture for the whole of the seven Basque territories. This is Gaindegia, the Basque observatory using Open Data, which can be accessed at www.gaindegia.eus and www.datuak.net.

Also, two centenary cultural societies, the Basque Society of Studies, Eusko Ikaskuntza, and the Academy for the Basque language, Euskaltzaindia collect data and generate autochtonous - local, original and autonomous - knowledge. One of their foundational visions was to collect and preserve relevant aspects of Basque culture through their ethnographic and folklore sections and the department on Basque dialects, before they faded away or evolved into modern technologies. This drive to collect data by ethnographer/anthropologists, linguists and archaeologists can be traced back to Larramendi, Peñaflorida and the Enlightenment, but was intensified by the influence of the romantics like von Humboldt and Lucien Bonaparte, and institutionalized by the founders of the two societies in 1918, namely Barandiaran, Aranzadi, Eguren, Azkue, and later by Caro Baroja and Mitxelena. Awareness of the need to collect and systematize data has a long and 
solid history for the Basques, and action was soon taken to do so, until the dictatorship put an end to such endeavors which, nevertheless, continued in exile, and were resumed and intensified since the 1970s, after the death of the dictator. All these are issues and areas where data become necessary for self-identification and self-awareness as a People and can be seen as examples of Indigenous or minority nation data governance in the Basque Country. This chapter cannot describe the whole data ecosystem in the Basque Country, but will look specifically at one particular aspect, the recent initiatives set up during the last decade in order to deal with the data and narratives dealing with the violent political conflict of the last 50 years.

\section{Data on memory and conflicting narratives: the Basque case}

In this contribution, we are interested in the datafication and categorization or labeling that leads to the construction of data related to politically motivated violence in the Basque Country. There are data collection and algorithmic strategies related to the major interests in constructing a narrative about the conflict. The key questions raised at the beginning of this section gain full relevance: everything about life, and death, that can be datafied will eventually be. But who, and for what purpose, is collecting and processing what data? Consequences depend on the type of data stored, the techniques used and on who decides about the knowledge and authority issues. This takes us to the heart of our contribution.

Powers over all matters related to justice and the criminal justice system are reserved to the central State (in a federal system, this would be equivalent to the federation, or the national, federal, level). The Spanish parliament has thus adopted the key legislation concerning amnesty, victims, terrorism, the Criminal Code and Criminal Procedure, execution of penalties and the prosecution service, the penitentiary law and such matters. There is little, if any, scope left at the regional or federated level even if any of these powers are devolved. The only devolution in the criminal justice system so far has been the transfer of the management of prisons to the Catalan government. As regards victims of political violence, the topic of this contribution, Spain has adopted three major legislative instruments:

1. the Amnesty Act of 1977, clearing all possible crimes committed before that year including those committed by the State or its organs. This meant full impunity for state crimes. Victims of such crimes would be left unattended.

2. the Act on Historical Memory 52/2007 of 26 December recognizes and expands rights and adopts measures in favor of those who suffered persecution or violence during the Civil War and the dictatorship.

3. the Act 29/2011 on the Recognition and Comprehensive Protection of Victims of Terrorism (amending and updating Act 32/1999 of 8 October).

These laws make up a specific system for the protection of victims that defines the conflict as one of terrorism, clears possible state crime and recognizes, in 
practice, only one category of victim of terrorism. Periodization becomes crucial, since the Amnesty law was adopted one year before the Spanish Constitution, which seems to mark a full stop and new period. Anything that happened before the Constitution (1978) is historical. Whatever took place, under the aegis of the state, within the constitutional regime could not possibly be in breach of human rights and would not be ascribed to the State.

Jon Landa (2019: 208) considers the Spanish system for the protection of victims of violence as having two major traits: asymmetry and hierarchy. It is asymmetric because there are different standards of protection-attention, reparation, recognition, homage - depending on the victim/perpetrator relation. These different standards are conditional, not on the type of breach or crime, but rather on the actor or perpetrator. The type of human rights violation may be the same, but the nature of the victim changes. In my analysis, this is the other side of the so-called criminal law of the enemy (Jakobs), the memory of "our" victims, victimized by our enemy. Victims of ETA terrorism have maximum protection. Victims of other forms of terrorism especially those linked to paramilitary groups often find obstacles in their recognition as victims of terrorism, and thus reparation is also blocked. The European Court of Human Rights ruled on July 18, 2019, that this differentiation in the status of victim, and this corollary denial of reparation does not breach the right to the presumption of innocence recognized in the Convention (Article 6, 2). ${ }^{4}$ Victims of the Historical Memory Act have a lower degree of reparation and recognition. Finally, victims of police abuses seeking recognition and reparation have sometimes seen the State questioning the perpetrations altogether, for cases occurring after 1978. This asymmetry and hierarchy of victims is builtin into the Spanish criminal justice system. It is supported by the major political parties in Spain.

The normative strategy adopted in the Basque Country (Basque Autonomous Community and Foral Community of Navarre) is within the framework of their limited powers, and always subject to the norms adopted by Spain. Therefore, the asymmetry and hierarchy of victims, depending on who was the perpetrator, still remains at large. The Basque Parliament adopted Act 4/2008 of June 19, 2008 , on victims of terrorism and the Basque Government adopted the decree 107/2012 of June 12 to repair victims of human rights abuses between 1978 and 1999. This was followed by Act 12/2016 of July 28 of the Basque Parliament, amended by Act 5/2019 of April 4, on recognition and reparation of those victims. The Navarre Foral Act 16/2015 of April 15 was enacted to recognize and repair victims of politically motivated acts of violence by groups of the extreme right or public servants. Both Acts, Basque and Navarrese, cover the final phase of the Franco dictatorship (1960-1978), in line with the Spanish Act on Historical Memory. This Act was declared unconstitutional by the Spanish Constitutional Court by a very thin majority alleging it invaded exclusive State powers to judicially declare that an individual was the victim of abuse by State servants. In a similar vein, the Basque Act 12/2016 of July 28, to recognize and repair victims of human rights abuses (1960-1978) was re-drafted in order to take into account that ruling, and the State announced it would not dispute the constitutionality of the 
Act. However, MPs of political grouping Ciudadanos and Popular Party of Spain both lodged actions for constitutional review. Navarre adopted a law on historical memory and the Basque Autonomous Parliament was presented with a citizens' legislative initiative with a Bill on the subject.

\section{Data and the "War" on numbers}

Behind such legislative framing of victims (and perpetrators), there are different views as to what the Basque conflict, giving rise to political violence, is really about. This generates different explanations or theories about the conflict. The framing of the narrative about the conflict then shapes the categorization of the victims and perpetrators, and the preconceptions about the type of data that need to be collected. The data about the conflict diverge along two major axes: numbers and labeling of "victims" and time-periods. The debates around the numbers of victims and casualties depend on how the conflict is narrated, and on the labels that are used. The "war" on numbers relates to whether one includes victims of police abuse. This affects the categorization of the data on victims. The most accurate approximation to the numbers has been carried out by the Basque Government reports. The Basque Government produced a report on breaches of human rights in the years 1960-2013 based on research by Carmena, Landa, Mugica and Uriarte. It gives the following numbers: victims killed by ETA were 837; victims wounded by ETA are 2600; victims killed by State-related terrorism (paramilitaries) were 73; victims wounded by State-related terrorism were 426; victims killed by the action of State agents were 94 and victims wounded by the action of State agents are 746. This report does not include cases of torture. Another Basque Government research report, on torture and degrading treatment between the years 1960 and 2014, documented 4000 cases of alleged torture by State agents. It was carried out by IVAC, the Basque University Institute of Criminology and the team of Etxeberria, Martin and Pego and contains conclusions and recommendations. These numbers and reports are yet to be complemented by other types of victims: those 511 local counselors threatened by ETA (between 1999 and 2011) and needing bodyguards (Report by U Deusto Pedro Arrupe Institute of Human Rights, July 12, 2019), those extorted or subjected to preventive ransom money. The data are yet to be gathered in official reports.

\section{Memorial data in the Basque conflict: two diverging sovereign views}

There have been a number of memorial initiatives that are generating and keeping archives and media, legal and historical data as regards the different episodes or expressions of political violence that have taken place in the Basque Country. The ceasefire declared by ETA in 2011, the decommissioning of its arsenal in April 2017 and its final dissolution in May 2018 are triggering a "competition" on data and on figures concerning the victims of the conflict. The narratives constructed around such figures and phenomena tend to diverge. Historians are drawn into the debate, and institutions are financing research and memorial 
projects to construct versions of the truth about the past. This section analyzes, on the basis of their own webpages and legislation, the two main victim-recognition initiatives, one, the Centro Memorial de Víctimas del Terrorismo, incorporated by Spanish Parliament Act 29/2011; the other, Gogora Institute, incorporated by Act 4/2014 of the Basque Parliament. The dynamics behind memory institutions, memorials and research projects launched and financed by the Spanish Government and those under the aegis of the Basque autonomous institutions all deal with the conflict in a certain way. But they frame it into different, not necessarily opposing, historical and normative narratives. These are not the only organizations dealing with memory of the violent conflict. There are several others, as mentioned below, and some of them have set up databases, repositories and listings. ${ }^{5}$ Ownership over the discourse about the conflict is no monopoly of any of them, but the official organizations, like the two here analyzed, are particularly important in that they are the result of the will of the legislature, the political representatives of the whole of Spain and of the Basque Autonomous Community.

\section{The Memorial Centre for the Victims of Terrorism}

Act 29/2011 of the Spanish Parliament on the Recognition and Comprehensive Protection of Victims of Terrorism established the Fundación Centro para la Memoria de las Víctimas del Terrorismo (FCMVT) as a state public sector foundation, affiliated with the Ministry of the Interior, with a collegiate-like governing body that includes representatives of the government of Spain as well as those of the autonomous communities, the Cortes Generales [Spanish Parliament], the City Council of Vitoria-Gasteiz and the victims of terrorism. Victims of terrorism are grouped into different organizations, each of which elaborates its own data on victims. The purpose of the center is to preserve and disseminate the democratic and ethical values embodied by the victims of terrorism, building the collective memory of the victims and raising awareness among the population as a whole for the defense of freedom and human rights and against terrorism. Having declared that the victims of terrorism constitute "an ethical reference for our democratic system" and that they "symbolise the defence of freedom and the Rule of Law against the terrorist threat", the legislators established that

"the public powers will contribute to the knowledge of the truth, attending to the real causes of the victims and contributing to an account of what happened that avoids moral or political equidistances, ambiguities or valuative (sic) neutrality, which reflects with absolute clarity the existence of victims and terrorists, of those who have suffered the damage and of those who have caused it, and which favors an outcome in which the victims feel supported and respected, without there being any justification for terrorism and terrorists".

These legal provisions establish the framework of principles under which the Memorial Center operates. They indicate a parti pris that gives victims of ETA 
terrorism an enhanced or privileged moral and political predicament. This transpires in their historiography.

The Memorial Center has a documentation center specialized in terrorism and victims of terrorism with a four-fold function: (1) ensure the conservation of the collections; (2) create and maintain a national digital reference repository; (3) facilitate research; and (4) provide items for permanent and temporary exhibitions. It aims to gather all the collections (or digital copies) related to the civic movement, the pacifist movement, victim associations and foundations, law enforcement bodies, terrorist groups etc. The priority is to recover, centralize and digitize all those bibliographic, documentary, newspaper, photographic and audio-visual collections that today remain dispersed and, in some cases, in bad condition or even in danger of disappearing. It will create a Memory Bank, especially focused on the custody of testimonies of victims of terrorism, both those already made and those that will be made in the future, but also those of other key stakeholders, such as members of law enforcement bodies, judges, lawyers, journalists, intellectuals etc.

The same report adds that

"a Memorial Centre brings together history and memories to reconstruct facts as accurately as possible and to extract the moral significance of the past for the present. As a result, in this Victims of Terrorism Memorial Centre, there will be an account of terrorism, the cause of victims, and the responsibilities of those who made it possible will be questioned in order to avoid it happening again.

The FCMVT is the first memorial center dedicated to the victims of terrorism in Europe and one of only a few in the world. It has been set up with one director (a journalist) and two sub-directors (historians), one media advisor and one lawyer, all male.

\section{Gogora Institute for Remembrance, living together, and human rights}

Gogora, (Memory or Bearing in Mind, in Basque) is an institutional forum where victims and society can share their remembrance of the past with a view to helping to build peaceful coexistence (living together). It was set up with the remit of coordinating public policies on remembrance in the Basque Country. Its job is to preserve and pass on the memory of the traumatic, violent and traumatic experiences of the past hundred years: the Civil War, the Franco dictatorship, the terrorism of ETA and unlawful counterterrorist attacks; memories of suffering unjustly caused and efforts to construct and defend democratic coexistence and a society based on human rights and peace, even in the most adverse circumstances.

Taking ethical responsibility for passing on democratic remembrance as its starting point, Gogora Institute seeks to establish inclusive remembrance, guaranteeing the engagement of the public. Only one limit is set on this dialog between memories: remembrance must not be used to exclude events or seek equivalences 
between them. Nor must it be used to justify any form of terrorism, violence or violation of human rights.

The prime function of Gogora is to coordinate public sector policy on remembrance. To that end, it coordinates the actions of the various institutions and social organizations that work in the field of remembrance and in promoting Human Rights, striving to achieve cooperation and collaboration between them, guaranteeing the broadest possible links with society.

Gogora Institute has four major functions:

1. commemoration: the organization of programs, publications, academic and cultural activities and events in general to keep alive the testimonies and memories of people and events significant for the formation of a free, democratic society.

2. conservation: the conserving of the heritage of democratic remembrance in the Basque Country in all its material forms. To that end, its activities shall include the establishment and maintenance of information archives and inventories of items and places linked to remembrance, be they objects, physical locations, social contexts or other elements that can serve for identification and social recognition.

3. research and investigation, including the reports on victims of the different acts of violence in the different periods covered. These reports are normally carried out by researchers from the Basque universities, with the additional involvement of the Basque Government or the provincial governments. Some of these reports have already been mentioned throughout this contribution.

4. education, participation and dissemination, integration and consultation of all affected.

The preface to Act 4/2014 establishing the Institute makes direct reference to democratic memory as being related to freedom, equality and dignity of the person. Memory is seen as a right, not a duty. It fulfills the need for critical thinking about a traumatic past of Human Rights violations and the will to share such thoughts. In Gogora's webpage periodization is analyzed, in line with its own statutes. Briefly summarized, over the last hundred years, Basque Society has experienced four traumas of violence: the Civil War and the Franco dictatorship that make up historical memory, and ETA terror and unlawful counterterrorism that make up recent memory. These traumas have occurred in different historical periods: the Civil War and early dictatorship, the emergence of ETA violence in the second half of the dictatorship, the transition and democracy. The four traumatic episodes of violence, different as they are, have something important in common: they violated individual human rights generating direct victims, and also indirect victims and thus, they all inflicted an unfair suffering on Basque society. The memory and appraisal of the recent memory cannot be carried out without distinguishing the different periods and contexts: the last years of the dictatorship, the "transition" and the democratic period. In the worst circumstances, 
Basques always aspired to live together in a democratic society based on freedom and peace and where human rights are observed.

\section{Two different approaches}

We have seen two different approaches to the memory of the victims of violent conflict: the Memorial Center closely follows the Spanish political system's view of the Basque conflict as reduced to ETA terrorism and its defeat by the democratic system and the Spanish security forces, and the Gogora Institute, which takes a larger view of the Basque conflict, going back 100 years and covering other forms of political violence; where ETA is the most important, but not the only, perpetrator of the recent memory period. The lexicon used in each of the memorials is notably different. Both are aiming to collect data and reconstruct facts as accurately as possible in order to preserve memory. The Memorial Center uses a securitarian semantic family_ "terrorist threat", "terrorists", "terrorism", "the real causes of the victims", "victims of terrorism" - together with the language of morality — "ethical values embodied by the victims of terrorism", victims of terrorism as an "ethical reference for our democratic system", creating an "account that avoids moral or political equidistances, ambiguities" or "value neutrality", reflect with "absolute clarity who suffered the damage and who caused it". The Memorial Center clearly states the moral superiority of the victims of terrorism, making no attempt to explain the political motivations behind the acts of "terrorism". There is no historical periodization. Victims of terrorism have moral truth on their side and the role of the historian and the memorial is to clarify that truth. ${ }^{6}$ This moral superiority of the victims of terrorism turns the unfairness and injustice of their victimhood into a higher "political" status, which leaves no scope for ambiguity, where victims can also be perpetrators, in different degrees, as pointed out in the introduction

By contrast, Gogora underlines and distinguishes historical periods and seeks an inclusive memory. It speaks of "democratic remembrance", "living together" (coexistence is the term sometimes used for the Spanish "convivencia" or the Basque "bizikidetza"), "democratic society", "Human Rights violations". The idea of inclusiveness and of consideration of all the variants of the violent conflict in the Basque Country is compatible with the moral rejection of all breaches of human rights. Remembrance must not be used to exclude events or seek equivalences between them. Nor must it be used to justify any form of terrorism, violence or violation of human rights. Victims and perpetrators are to be found in all sorts of camps and are not as neatly categorized into good and evil, and the ethical lessons or morale is to condemn all forms of violence. This approach is criticized by scholars involved with the Memorial Center. ${ }^{7}$

\section{Conclusion: labeling and data}

The different approaches of the victims and memory policies and their data governance have implications on the narratives of Basque conflict political violence. I find it impossible for any scholar in the Humanities and Social Sciences to take a 
neutral approach. My aspiration is impartiality and "equidistance", understood as equal rejection of all human rights abuses, whatever their source and their perpetrator. Equidistance should not mean that all actors in the conflict have committed the same amounts of harm, an area where data on victims becomes relevant, but all violations of human rights are blameworthy. Some violations are more serious than others. Yet difference in degree is not difference in nature; none can be excused, especially not on the grounds that the "other" has also committed a violation. A "terrorist" who is tortured or sent to distant prisons in isolation, becomes a victim. This victim status does not mitigate in any way the moral and legal blameworthiness of his crime. The moral superiority attached to victims lies in the fact that they never chose that status nor their suffering as victims, and their victimizers have the full moral blame because they chose to kill them or harm them.

ETA presented its victims as though they were casualties of a Basque "conflict", thus disguised their deliberate choice to harm each and every one of them. ETA hid behind the rhetoric of "armed conflict" with Spain in order to eschew ethical blameworthiness. Its victims were, instead, casualties of the struggle for freedom. The Franco dictatorship, after the Civil War, did the same toward the Republican "reds and separatists". But they were not casualties of war: they were killed, disappeared and persecuted for their ideas. The fight against ETA by constitutional Spain has similarly used the "rule of law" (Estado de derecho) as an excuse to hide from the moral harm caused by its decisions: to send ETA prisoners to far-away prisons, to block investigation of torture allegations, to deny the status of victims of terrorism to victims of paramilitary groups, to deny progress in grade to ETA prisoners, and other direct abuses.

Victims are always passive as victims, but sometimes victims are also perpetrators, and that is why turning the victim into an absolute category, implying a status of moral superiority is not morally credible. A "terrorist" and a "victim of terrorism" are not absolute categories, they are not permanent status or predicaments. A "former terrorist" and a "former torturer" can regain their dignity and aspire to live together, when they assume responsibility for the harm they created. This is the aspiration of an enlightened criminal justice system based on the dignity of the person. We need to become aware of the suffering we inflict, and sensitive to the suffering of all, including those we, wrongly, consider our "enemies". Data governance on memory of victims should take these considerations into account and reflect deeply on the labels used and the periods selected for the data. Furthermore, the interests and agendas of data collectors should be examined thoroughly as well. I hope to have contributed to making this point.

\section{Notes}

1 The research leading to this chapter has been done in the framework of Research Group GI UPV/EHU on Derechos Fundamentales y Unión Europea” IT1190-19the EU and Fundamental Rights (Unión Europea y Derechos Fundamentales) and also Research Program DER 2015-64599-P MINECO/FEDER UE "Factores postdelictivos y peligrosidad postdelictual"". 
2 In 2001, the Spanish Government posthumously awarded him the golden medal on Civil Merit. ETA's first mortal and last victims, Civil Guard Pardines in 1968 and Gendarme Nerin in 2010 were both shot in police traffic checks.

3 Boaventura de Sousa Santos (2014).

4 The two cases (Larrañaga Arando and Others v. Spain and Martinez Agirre and Others v. Spain) concern the relatives of six victims killed by paramilitary groups. A 1983 Council of Europe Convention on Compensation of Victims of Violent Crimes allows withholding compensation if the victims had any relation with a violent organization. In my view, the case should have been brought under Protocol 1 of the Convention, in relation to Article 14.

5 Some organizations representing victims of ETA are AVT, FVT, or Covite. Some organizations from a Basque perspective are Argituz, Euskal Memoria, or Egiari Zor. Their websites contain interesting information.

6 Rivera (2018:13).

7 Rivera (2018) blames the Basque Government for carrying out memory without history, (17) and putting the different forms of violence at the same level (23).

\section{References}

Bullain, I. (2011). Revolucionarismo Patriótico. Tecnos, Madrid.

Cossins, D. (2018). Discriminating algorithms: 5 times AI showed prejudice. New Scientist. https:/www.newscientist.com/article/2166207-discriminating-algorithms-5-times-aishowed-prejudice/.

Landa, J. (2019). Biktimei buruzko politikak Euskadin: balantze labur bat eta etorkizuneko perspektibak. In J.M.L. Gorostiza and E.G. Carrera (eds.), Euskadi Indarkeriaren Ondoren- Euskadi Después de la Violencia, UPV/EHU Argitalpen Zerbitzua, Bilbao, 203-225.

Lovett, R., Lee, V., Kukutai, T., Rainie, S.C., and Walker, J. (2019). Good data practices for indigenous data sovereignty. In A. Daly, K. Devitt, and M. Mann (eds.), Good Data. Institute of Network Cultures, Inc., Amsterdam. ISBN:978-94-92302-27-4.

Kukutai, T., and Taylor, J. eds. (2016). In T. Kukutai and J. Taylor (eds.), Indigenous Data Sovereignty: Toward an Agenda. Australian National University Press.

Rainie, S.C., Kukutai, T., Walter, M., Figueroa-Rodriguez, O.L., Walker, J., and Axelsson, P. (2019). Issues in open data: indigenous data sovereignty. In T. Davies, S. Walker, M. Rubinstein, and F. Perini (eds.), The State of Open Data: Histories and Horizons. African Minds and International Development Research Centre, Cape Town and Ottawa, 300-319.

Rivera, A. (2018). El pasado como posibilidad. In A. Rivera (ed.), Naturaleza Muerta. Usos del Pasado en Euskadi Después del Terrorismo. Prensas de la Universidad de Zaragoza, Zaragoza.

Snipp, C.M. (2016). What does data sovereignty imply: what does it looklike? In T. Kukutai and J. Taylor (eds.), Indigenous Data Sovereignty: Toward an Agenda. ANU Press.

de Sousa Santons, B., del Sur, E., and Barcelona, A. (2014). Epistemologies of the South. London: Routledge.

Walter, M. (2018). The voice of indigenous data: beyond the markers of disadvantage. First Things First, Griffith Review, 2018(60), 256-263. 